\title{
Anhaltende Haushaltsüberschüsse - Zeit für Steuersenkungen?
}

Deutschland hat mittlerweile seit acht Jahren Überschüsse oder ausgeglichene öffentliche Haushalte zu verzeichnen. Entsprechend ist auch die Schuldenstandsquote so weit gesunken, dass das Maastricht-Kriterium wieder eingehalten wird. Diese durch einen langanhaltenden wirtschaftlichen Aufschwung begünstigte Entwicklung führt zu Streit darüber, wie die Überschüsse verwendet werden sollen. Einerseits gibt es einen Konsens, dass dringend Investitionen für die Klima- und Verkehrswende sowie für mehr Bildung und Innovationen benötigt werden, andererseits sehen einige die Wettbewerbsfähigkeit Deutschlands gefährdet, weil Unternehmen steuerlich überdurchschnittlich belastet seien. Die gute Haushaltslage könnte es aber auch erleichtern, eine grundlegende Reform des Steuer- und Abgabensystems durchzusetzen. Dabei sollte beachtet werden, dass Änderungen im Steuersystem ganz unterschiedliche Wirkungen auf die oberen oder die unteren Einkommensgruppen haben.

Steuersenkungen - Wenn nicht jetzt, wann dann?

Stefan Homburg, Leibniz Universität Hannover.

Strukturverschiebung im gesamten Abgabensystem erforderlich!

Margit Schratzenstaller, Österreichisches Institut für Wirtschaftsforschung (WIFO) und Universität Wien.

Acht Elemente einer grundlegenden Reform des Steuer- und Transfersystems

Andreas Peichl, ifo Institut und Ludwig-Maximilians-Universität München.

Clemens Fuest, ifo Institut und Ludwig-Maximilians-Universität München.

Zeit für Wachstumspolitik

Michael Hüther, Institut der deutschen Wirtschaft (IW).

Steuersenkungen: untere und mittlere Einkommen entlasten!

Stefan Bach, Deutsches Institut für Wirtschaftsforschung (DIW) Berlin.

Wenig Spielraum für dauerhafte Nettoentlastungen

Achim Truger, Universität Duisburg-Essen; Sachverständigenrat zur Begutachtung der gesamtwirtschaftlichen Entwicklung, Wiesbaden.

Title: Sustained Budget Surpluses - Time for Tax Cuts?

Abstract: Germany has now been running surpluses or balancing its public budgets for eight years. Accordingly, the debt-to-GDP ratio has fallen to such an extent that the Maastricht criterion is once again being met. This development, which has been favoured by a prolonged economic upturn, has led to disputes about how the surpluses should be used. On the one hand, there is a consensus that investment is urgently needed to turn the tide on climate change and transportation and for more education and innovation, while on the other hand some see Germany's competitiveness as being at risk because of the above-average tax burden on companies. The favourable budget situation could also make it easier to push through a fundamental reform of the tax and contribution system. However, it should be borne in mind that changes in the tax system have very different effects on upper and lower income groups.

JEL Classification: H2O, H60, D31 